\title{
ASSESSING THE POST-HARVEST CHEMICAL AND MICROBIAL CHANGES IN THE MEAT OF ROHU (Labeo rohita) KEPT UNDER DIFFERENT STORAGE CONDITIONS
}

\author{
Shahbaz Ahmad Dar* and Abdul Mateen
Saline Fisheries Laboratory, Department of Zoology, Wildlife and Fisheries, University of Agriculture, Faisalabad- 38040, Pakistan \\ *Corresponding author's e-mail: profshahbazdar@gmail.com
}

\begin{abstract}
The present study was designed to investigate the post-harvest chemical and microbial changes in the meat/muscle of Labeo rohita kept under storage conditions including icing, salting and sun-drying for the period of $0,1,3,7,14$ and 30 days. The chemical and microbial analysis of fish meat was performed and the results revealed that after 30 days of storage, the moisture contents $(21.27 \pm 0.34$ to $79.10 \pm 1.85 \%)$ and total volatile base nitrogen $(21.74 \pm 0.33$ to $26.20 \pm 0.50 \mathrm{mg} / 100 \mathrm{~g})$ were higher in icing and lower in sun-drying condition while crude protein $(16.00 \pm 0.10$ to $59.30 \pm 0.21 \%)$, crude fat $(1.50 \pm 0.04$ to $10.83 \pm 0.08 \%)$ and $\mathrm{pH}(6.90 \pm 0.07$ to $7.98 \pm 0.06)$ were observed higher in sun-drying and lower in icing condition. Ash contents $(1.52 \pm 0.02$ to $25.40 \pm 0.10 \%)$ and protein solubility $(40.23 \pm 0.03$ to $48.10 \pm 0.35 \%)$ of fish meat were found higher in salting condition while ash contents and protein solubility were lower in icing and sun-drying conditions, respectively. Microbial analysis of fish meat showed maximum total plate count (TPC) $5.81 \pm 0.03 \log _{10}$ CFU/g in sun-drying and minimum TPC $4.16 \pm 0.05 \log _{10} \mathrm{CFU} / \mathrm{g}$ in salting condition. All results were found significant at $\mathrm{p}<0.05$. These findings could benefit all the stakeholders to formulate laws and promote the application of the improved methods and good handling practices to minimize post-harvest losses.
\end{abstract}

Keywords: Freshwater fish, quality assessment, proximate composition, icing, salting, sun-drying.

\section{INTRODUCTION}

The fisheries sector is a major source of food, livelihood, and decor recreational activities worldwide. Aquaculture and capture fisheries have contributed about 179 million tons of fish in 2015 around the world (FAO, 2015). Cyprinids are the most cultured species in the world with $40 \%$ production by volume. Pakistan's total fisheries production stood at 725,000 tons in 2012. Fish exports declined to 126,200 tons in the financial year 2012 which were 128,900 tons during the year 2011.

The decline in exports and loss of foreign exchange may be due to poor management and storage issues. Pakistan fishing industry is facing problems in technical, regulatory and operational fields. Fishing makes a considerable contribution to the economy of many countries that have fishing as an established field. Small-scale fisheries of developing countries are very important because they provide a nutritious food, which is often cheaper than meat; therefore, accessible to a larger number of people (Jim et al., 2017).

Fish is a major source of protein, fat, minerals, vitamin and valuable omega-3 fatty acids contributing to food and nutrition security (Mohan et al.,2016). Despite such a nutritional importance fish is highly perishable food, which could be rendered unfit for human consumption within twelve hours of capture at tropical temperature conditions (Jim et al., 2017). The quality of fish meat and its usefulness is affected by the capture methods, handling practices, processing methods, distribution techniques and storage conditions (Tesfay and Teferi, 2017).

A number of post-harvest methods for storage are being used and these modern and improved preservation and processing techniques like drying, smoking, chilling and salting greatly minimize the spoilage of fish meat (Getu et al.,2015). One such method for preservation of fish is the icing where a fish can be stored for up to three months without changing the colour, texture, and taste of the fish flesh (Mohan et al., 2016). There are very limited reports on the evaluation of functional properties of fish protein stored under icing and icing storage (Mohan et al., 2016). However, the quality of fish meat during iced storage deteriorates because the fish meat has a high proportion of proteins and unsaturated fatty acid (Tesfay and Teferi, 2017). Another method for the preservation purpose is drying (Kumar et al., 2013), which is a physical process wherein fish is exposed to air and direct sunlight for different intervals of time depending upon its type. Fish products when treated with high temperature for a long time increases the degradation of protein and oxidation of fatty acids (Kumar et al., 2013). Another method used for fish preservation purpose is salting, which is considered as the most primitive method and is still being used around the globe (Ormanci and Colakoglu, 2015). This method is a very popular in many 
parts of the world and has been proven to be very safe for decades (Getu et al., 2015). Salting of fish is done to reduce the moisture content and inhibits the growth of spoilage microorganisms (Ormanci and Colakoglu, 2015).

This study assessed the fishing practices employed by fishermen and fish processors during harvesting, transportation, processing and packaging of fish and the effects of post-harvest handling of fish. The present project was therefore been carried out with the objective of comparing the effect of storage time and conditions on the nutritive values of $L$. rohita an indigenous carp. The other main objective was to evaluate the functional properties of proteins of $L$. rohita in relation to conformational changes using different preservative techniques.

\section{MATERIALS AND METHODS}

The research was conducted at Fisheries Research Farms and Saline Fisheries Laboratory, Department of Zoology, Wildlife and Fisheries, University of Agriculture, Faisalabad, Pakistan. The fishes (580-670 g) were collected from earthen ponds and subjected to three selected post-harvest techniques i.e., icing, salting, and sun drying. The post-harvest chemical and microbial changes evaluated in terms of proximate analysis, proteins solubility, total volatile base nitrogen, $\mathrm{pH}$ and total plate count following the standard methods of AOAC $(2005,2010)$. For this purpose, samples were drawn at $0,1,3,7,14$ and 30 days of storage.

Preparation of sample: The fish fillets were prepared according to the methodology described by Khan et al, (2011).

Icing: The fish fillets were collected and transferred to thermocol boxes and iced in the ratio of $1: 1$. The boxes were placed in a chill room around $4{ }^{\circ} \mathrm{C}$ for storage studies. The ice was replaced on daily bases after draining water.

Salting: Fish fillets were weighed by using a digital balance for the purpose of salting, salt was applied $25 \%$ of the fish weight.

Sun drying: During sun drying surface water of fillets was removed by soaking paper before conducting the experiments. A steel wire mesh tray of $0.30 \times 0.25 \mathrm{~m}$ was used for open sun-drying of fish. During experiments, the ambient air temperature was $35-40^{\circ} \mathrm{C}$.

Chemical and Microbial Analysis

Moisture: The moisture contents were determined by hot air oven method (AOAC, 2010).

Crude protein $(C P)$ : The protein contents of the fish meat were calculated by estimating its total nitrogen by Kjeldahl method (AOAC, 2010).

Crude fat $(\boldsymbol{C F})$ : Crude fat contents were determined using the Soxhlet apparatus (AOAC, 2005).

Ash: Ash was determined by placing the samples in the muffle furnace at $550^{\circ} \mathrm{C}$ for 8-12 h (AOAC, 2005).
Protein solubility (PS): The solubility of proteins was determined according to the method of Rodriguez et al. (2005). Protein contents in the supernatant were calculated by using the Bradford (1976) method.

Total volatile base nitrogen (TVBN): The total volatile base nitrogen was determined by Conway's micro-diffusion analysis (Osman et al., 2001). The TVBN content was expressed as milligram nitrogen per $100 \mathrm{~g}$ sample.

$\mathrm{pH}$ : $\mathrm{pH}$ value was determined by using a glass electrode of a newly calibrated digital $\mathrm{pH}$ meter (JENWAY-3015 pH meter).

Total plate count (TPC): Fish meat (10 g) meat was homogenized aseptically with $90 \mathrm{~mL}$ of sterile physiological saline $(0.85 \% \mathrm{NaCl})$ for $3 \mathrm{~min}$. Appropriate dilutions were made and poured onto agar plates by spread plate technique. The plates were incubated for $24 \mathrm{~h}$ at room temperature. Total plate count (TPC) was enumerated and expressed as a number of colonies forming units per gram.

Statistical analysis: Statistical analysis of meat quality parameters was done by one-way ANOVA and Tukey`s test was used to compare the difference between means. Statistical Package for Social Science (SPSS) was used.

\section{RESULTS}

Post-harvest proximate analysis of Labeo rohita meat at the end of 30 days storage conditions showed that the maximum values of moisture contents $79.10 \pm 1.85 \%$ were measured in icing while minimum moisture contents $21.27 \pm 0.34 \%$ measured in sun-drying condition. High values of crude protein $59.30 \pm 0.21 \%$ and crude fat $10.83 \pm 0.08 \%$ were observed in sun-drying. Whereas low crude protein $16.00 \pm 0.10 \%$ and crude fat $1.50 \pm 0.02 \%$ values were observed in icing and salting condition respectively. Ash contents $25.40 \pm 0.10 \%$ was observed higher in salting and lower $1.52 \pm 0.02 \%$ in icing conditions. Post - harvest results showed that in icing conditions, moisture and ash contents of meat differ non-significant $\mathrm{p}<0.05$ while crude protein and crude fat differ significantly. Among salting and sun drying conditions, moisture, crude protein, crude fat, and ash values were significantly changed (Table 1).

Among chemical and microbial analysis, protein solubility $(46.40 \pm 0.51 \mathrm{mg} / 100 \mathrm{~g}, 48.10 \pm 0.35 \mathrm{mg} / 100 \mathrm{~g}$ and $40.23 \pm 0.03$ $\mathrm{mg} / 100 \mathrm{~g}$ ), decreased significantly in icing, salting and sun drying respectively. Whereas TVBN values increased significantly at the end of the 30 days storage conditions in icing, salting and sun drying as shown in table 2 and similar trends were observed regarding $\mathrm{pH}$ values in different storage conditions except in icing where change was observed nonsignificant.

The TPC values of meat were observed in $L$. rohita as $5.74 \pm 0.09 \log _{10} \mathrm{CFU} / \mathrm{g}$ during icing, $4.16 \pm 0.05 \log _{10} \mathrm{CFU} / \mathrm{g}$ salting, 5.81 $\pm 0.03 \log _{10} \mathrm{CFU} / \mathrm{g}$ and sun drying conditions respectively. Post-harvest analysis indicates that the TPC of 
Table 1. Post-harvest proximate analysis of Labeo rohita under different storage conditions. Values are given as Mean \pm SE of three independent experiments performed in triplicate. Data were analysed using one way ANOVA followed by Tukey's test.

\begin{tabular}{lcrrr}
\hline Proximate & Initial values & \multicolumn{3}{c}{ Final values after 30 days of storage } \\
\cline { 2 - 4 } composition indices & & Icing & Salting & Sun drying \\
\hline Moisture \% & $76.60 \pm 0.55^{\mathrm{a}}$ & $79.10 \pm 1.85^{\mathrm{a}}$ & $56.23 \pm 0.52^{\mathrm{b}}$ & $21.27 \pm 0.34^{\mathrm{c}}$ \\
Crude protein \% & $18.20 \pm 0.08^{\mathrm{b}}$ & $16.00 \pm 0.10^{\mathrm{c}}$ & $16.80 \pm 0.12^{\mathrm{c}}$ & $59.30 \pm 0.21^{\mathrm{a}}$ \\
Crude fat \% & $2.60 \pm 0.02^{\mathrm{b}}$ & $1.50 \pm 0.04^{\mathrm{c}}$ & $1.50 \pm 0.02^{\mathrm{c}}$ & $10.83 \pm 0.08^{\mathrm{a}}$ \\
Ash \% & $1.79 \pm 0.02^{\mathrm{c}}$ & $1.52 \pm 0.02^{\mathrm{c}}$ & $25.40 \pm 0.10^{\mathrm{a}}$ & $12.89 \pm 0.20^{\mathrm{b}}$ \\
\hline
\end{tabular}

Means sharing the similar letter in a row are statistically non-significant $(\mathrm{P}<0.05)$

Table 2. Post-harvest chemical and microbial analysis of Labeo rohita under different storage conditions. Values are given as Mean $\pm \mathrm{SE}$ of three independent experiments performed in triplicate. Data were analysed using one way ANOVA followed by Tukey's test.

\begin{tabular}{lcrrr}
\hline Parameters & Initial values & \multicolumn{3}{c}{ Final values after 30 days of storage } \\
\cline { 3 - 5 } & & \multicolumn{1}{c}{ Icing } & Salting & Sun drying \\
\hline Protein solubility \% & $72.60 \pm 0.54^{\mathrm{a}}$ & $46.40 \pm 0.51^{\mathrm{b}}$ & $48.10 \pm 0.35^{\mathrm{b}}$ & $40.23 \pm 0.03^{\mathrm{c}}$ \\
TVBN mg/100 g & $7.90 \pm 0.14^{\mathrm{d}}$ & $26.20 \pm 0.50^{\mathrm{a}}$ & $24.20 \pm 0.39^{\mathrm{b}}$ & $21.74 \pm 0.33^{\mathrm{c}}$ \\
$\mathrm{pH}$ & $6.92 \pm 0.05^{\mathrm{b}}$ & $6.90 \pm 0.07^{\mathrm{b}}$ & $7.68 \pm 0.05^{\mathrm{a}}$ & $7.98 \pm 0.06^{\mathrm{a}}$ \\
TPC $\log 10 \mathrm{cfu} / \mathrm{g}$ & $5.28 \pm 0.05^{\mathrm{b}}$ & $5.74 \pm 0.09^{\mathrm{a}}$ & $4.16 \pm 0.05^{\mathrm{c}}$ & $5.81 \pm 0.03^{\mathrm{a}}$ \\
\hline
\end{tabular}

Means sharing the similar letter in a row are statistically non-significant $(\mathrm{P}<0.05)$

meat were statistically significant in fish subjected to icing, salting and sun drying conditions (Table 2).

\section{DISCUSSION}

The result revealed a significant difference $(\mathrm{p}<0.05)$ in moisture content of $L$. rohita meat during storage conditions of icing, salting, and sun drying. Moisture content remained maximum during the icing and decreased significantly during salting and sun drying conditions respectively. An increase in moisture content may be attributed to the loss of water holding capacity of fish, meat during icing, is consistent with the finding of Siddique et al. (2011). Dry salting produces considerable loss of constituent water due to the heavy uptake of salt in the fish muscles (Ormanci and Colakoglu, 2015). Dried fish has lower moisture contents due to evaporation than that of fresh fish (Ogbonnaya and Shaba, 2009).

The crude protein contents differ significantly in icing, salting, and sun-drying conditions. The crude protein content was non-significant in icing and salting conditions. The crude protein values of fish meat in sun drying condition were found significantly higher as compared to the initial value at the end of 30 days of storage (Kumar et al., 2013). According to Ormanci and Colakoglu (2015), crude protein in fish decreases could be due to denaturation of protein at high salt concentration. The increase of crude protein content under sun drying, storage condition was mainly because of loss of water that existed among the protein resulting in aggregation of protein, therefore protein contents remained high in dry fish meat (Immaculate et al., 2012). Ogbonnaya and Shaba (2009) described that protein was not denatured during sun drying; therefore, protein increases with the reduction of moisture in the fish samples.

The crude fat contents in the meat of $L$. rohita were found significantly different at the end of 30 days of storage conditions of icing, salting and sun drying as compared to the initial value of fish meat just after harvesting. The crude fat contents in fish meat increased significantly in the sun drying condition, but decrease in icing and salting conditions. The result of Gandotra et al. (2012) showed that the fat content in L. rohita decreased during icing for 21 days on $-12 \pm 2^{\circ} \mathrm{C}$. The decrease in fat content in icing condition is related to fat oxidation as explained by Al-Ghanim (2016). Salting processes and different level of salt concentration do affect fat contents of fish. Meat loss might be due to fat with exuded fluids with osmotic effect (Gandotra et al., 2012) Crude fat content in sun-dried sardines ranged from $7 \%$ to $16 \%$ were reported by Kolakowska and Sikorski (2010), for fish that were sun-dried. There is usually a considerable seasonal variation in the fat content of fatty fish; Sardines, sprats and mackerel (Zlatanos and Laskaridis, 2007).

The ash contents in the meat of $L$. rohita were found significantly different at the end of storage conditions of icing, salting and sun drying as compared to the initial value of fish meat just after harvesting. The ash contents in fish, meat increase significantly in salting and sun-drying conditions but decrease significantly in icing conditions. A significant decrease in ash contents during ice storage was reported by Gandotra et al. (2014) in L. rohita. The decrease in ash content was attributed to the drip loss during icing $\mathrm{Al}-$ Ghanim (2016). Ormanci and Colakoglu (2015) noted an increase in ash content in fish treated by dry salting. Ash 
values of L. rohita increased at the end of 30 days of sun drying condition. The increase in ash content is mainly because inorganic substance remains as ash during the ignition of organic matter (Immaculate et al., 2012).

At the time of harvesting, mean protein solubility (PS) values of $L$. rohita meat was found greater and at the end of 30 days of storage, which decreased significantly in icing, salting and sun drying conditions. The decreased protein solubility in ice stored fish is mainly due to clump and denaturation of myofibrils in fish meat (Mehta et al., 2011). In salt storage condition mean protein solubility values of $L$. rohita was found lower at the end of 30 days of storage. Mean protein solubility was significantly changed, due to protein denaturation associated with its hydrophobicity and hydrophilic stability (Mostafa and Salem, 2015).

Total volatile base nitrogen (TVBN) content is one way to decide the freshness of fish products. TVBN in the meat is chiefly contributed by ammonia produced as a result of deamination muscular proteins (Kumar et al., 2013). Following the harvesting, mean TVBN values of $L$. rohita were lower and at the end of 30 days of storage. They increased significantly under icing, salting and sun drying conditions. TVBN value is increased due to the bacterial degeneration and enzymatic activity of endogenous enzymes (Mehta and Shamasundra, 2015).

The $\mathrm{pH}$ values of $L$. rohita meat increase significantly in salting and sun drying conditions but it decreases in icing condition. Mehta and Shamasundra (2015) observed changes in $\mathrm{pH}$ values of $L$. rohita during 22 days of icing condition. The $\mathrm{pH}$ of the freshwater fish muscle exhibited a decreasing trend in the course of ice storage. An increase in $\mathrm{pH}$ may be attributed to the production of volatile basic components such as ammonia, TMO and total volatile nitrogen by fish spoilage bacteria (Islami et al., 2015). The $\mathrm{pH}$ of meat increase during storage in sun drying condition which shows degradation over time as reported by (Kumar et al., 2013).

At the end of 30 days storage, the TPC of L. rohita meat was increased significantly in icing, and sun-drying conditions but decrease significantly in salting condition. Mehta and Shamasundra (2015) reported that TPC increases in indigenous carps at the end of 22 days of ice storage. The mean TPC values of $L$. rohita at the end of salt storage condition was comparable with the result obtained (Mostafa and Salem, 2015) in salted grey mullet. During sun drying condition the TPC values of $L$. rohita meat were increased. The possible sources of high microbial counts in dried sardines are poor sanitary conditions during fishing, drying, storage and transportation (Abowei and Tawar, 2011).

Conclusion: Conventional post-harvest techniques (icing, salting and sun-drying) affected meat quality of L. rohita (an indigenous carp) and the fish stored in ice showed better meat and nutritive quality as compared to salted and sun-dried fish. To prevent post-harvest losses of fish, improved methods and good handling practices are required. High-quality fish could create further marketing opportunities both locally and internationally. The findings of this study could benefit all stakeholders including consumers, Fisher and policymakers to formulate laws and promote the application of the improved methods and good handling practices to minimize post-harvest losses.

Acknowledgement: The authors are highly thankful to the Higher Education Commission (HEC), Pakistan and Department of Zoology, Wildlife and Fisheries, University of Agriculture, Faisalabad, Pakistan.

\section{REFERENCES}

Abowei, J.F.N. and C.C. Tawar. 2011. Some basic principles of fish processing in Nigeria. Asian J. Agric. Sci. 3:437452.

Al-Ghanim, K.A., 2016. Effect of Different Storage Temperatures on Chemical Composition and Sensory Attributes of the Flesh of Cyprinus carpio and Clarias gariepinus. Pakistan J. Zool. 48:305-310.

AOAC. 2005. Official methods of analysis. Association of Official Analytical Chemists, Inc., Washington, DC, USA.

AOAC. 2010. Official methods of analysis. Association of Official Analytical Chemists, Inc., Washington, DC, USA.

Bradford, M.M., 1976. A rapid and sensitive method for the quantitation of microgram quantities of protein utilizing the principle of protein-dye binding. Anal. Biochem. 72:248-254.

FAO. 2015. The state of world fisheries and aquaculture. Food and Agricultural Organizations of the United Nations, Rome.

Gandotra, R., V. Gupta, M. Koul, S. Gupta, D. Parihar and R. Kumasi. 2014. The Effect of Ascorbic Acid and Citric Acid Solution Treatment on the Flesh Quality of Wallago attu. Int. J. Sci. Technol. 2:110-115.

Gandotra, R., M. Koul, S. Gupta and S. Sharma. 2012. Changes in proximate composition and microbial count by low-temperature preservation in the fish muscle of Labeo rohita (Ham-Buch). J. Pharm. Biol. Sci. 2:13-17.

Getu, A., K. Misganaw and M. Bazezew. 2015. Postharvesting and Major Related Problems of Fish Production. Fish Aquac. J. 6:154. doi:10.4172/21503508.1000154.

Immaculate, J., P. Sinduja and P. Jamila. 2012. Biochemical and microbial qualities of Sardinella fimbriata sun dried in different methods. Int. Food Res. J., 19:1699-1703.

Islami, S.N., M. Faisal, M. Akter, M.S. Reza, and M. Kamal. 2015. Comparative shelf life study of whole fish and fillets of cultured striped catfish (Pangasianodon 
hypophthalmus) during ice storage condition. Res. Agricult. 2:177-183.

Jim, F., P. Garamumhango, and C. Musara. 2017. Comparative Analysis of Nutritional Value of Oreochromis niloticus (Linnaeus), Nile Tilapia, Meat from Three Different Ecosystems. J. Food Qual. https://doi.org/10.1155/2017/6714347.

Khan, N., N.A. Qureshi, M. Nasir, F. Rasool and K.J. Iqbal. 2011. Effect of artificial diet and culture systems on sensory quality of fried fish flesh of Indian Major Carps. Pakistan J. Zool. 43:1177-1182.

Kolakowska, A. and Z.E. Sikorski. 2010. Chemical and Functional Properties of Food Lipids. $2^{\text {nd }} \mathrm{Ed}$. Taylor and Francis Group. CRC Press, New York. pp.279-306.

Kumar, A., P. Singh and M. Danish. 2013. Changes in proximate, biochemical and microbiological characteristics of dried Labeo gonius fillets during storage at room temperature. Afr. J. Biotechnol. 12:29973005.

Mehta, N.K. and B.A. Shamasundra. 2015. Changes in the chemical and sensory properties of freshwater fish (Indian major carps) during ice storage. Prog. Agric. 15:202-207.

Mehta, N.K., K. Elavarasan, A.M. Reddy and B.A. Shamasundra. 2011. Effect of ice storage on the functional properties of proteins from a few species of freshwater fish (Indian major carps) with special emphasis on gel-forming ability. J. Food Sci. Technol. 15:202-207.

Mohan, R. Shankar and S. Gopal. 2016. Packaging Interventions in Low-Temperature Preservation of Fish A Review. MOJ Food Process Technolp. 2:00026. DOI: 10. 15406/mojfpt.2016.02.00026.
Mostafa, A.A. and R.H. Salem. 2015. Characterization of Microbiological and Nutritional variation in processed Mullet (Magil cephalus) fish. Int. J. Microb. Res. 6:108122.

Ogbonnaya, C. and I.M. Shaba. 2009. Effects of drying methods on proximate composition of cat fish (Clarius gariepinus). World J. Agric. Sci. 5:114-116.

Osman, N.H., A.R. Suriah and E.C. Law. 2001. Fatty acid composition and cholesterol content of selected marine fish in Malaysian waters. Food Chem. 73:55-60.

Ormanci, H.B. and F.A. Colakoglu. 2015. Nutritional and sensory properties of salted fish product, lakerda. Cogent Food Agric. 1:1008348 http://dx.doi.org/10.1080/ 23311932. 2015.1008348.

Rodriguez-Ambriz, S., A. Martinez-Ayala, F. Millan and G. Davila-Ortiz. 2005. Composition and functional properties of Lupinus campestris protein isolates. Plant Foods Hum. Nutr. 60:99-107.

Siddique, M.N., M.J. Hasan, M.Z. Reza, M.R. Islam, M. Boduruzaman, M. Forhadur and S. Reza. 2011. Effect of freezing time on the nutritional value of Jatpunti (Puntius sophore), Sarpunti ( $P$. sarana) and Thaisarpunti ( $P$. gonionotus). Bangladesh Res. Public J. 5:387-392.

Tesfay, S. and M. Teferi. 2017. Assessment of fish postharvest losses in Tekeze dam and Lake Hashenge fishery associations: northern Ethiopia. Agric. and Food Secur. 6:1-12. DOI 10.1186/s40066-016-0081-5.

Zlatanos, S. and K. Laskaridis. 2007. Seasonal variation in the fatty acid composition of three Mediterranean fishsardine (Sardina pilchardus), anchovy (Engraulis encrasicholus) and picarel (Spicara smaris). J. Food Chem. 103:725-728. 